\title{
Burrowing into the reciprocal learning collaboration of two instructors in an English- medium university in Turkey
}

Jennifer Mitton-Kükner \& Çiler Akyűz

To cite this article: Jennifer Mitton-Kükner \& Çiler Akyűz (2012) Burrowing into the reciprocal learning collaboration of two instructors in an English-medium university in Turkey, Teacher Development, 16:4, 425-442, DOI: 10.1080/13664530.2012.717213

To link to this article: https://doi.org/10.1080/13664530.2012.717213

Published online: 29 Aug 2012.

Submit your article to this journal $\square$

Џلll Article views: 192

4 Citing articles: 2 View citing articles ๘ 


\title{
Burrowing into the reciprocal learning collaboration of two instructors in an English-medium university in Turkey
}

\author{
Jennifer Mitton-Kükner ${ }^{\mathrm{a} *}$ and Çiler Akyüz ${ }^{\mathrm{b}}$ \\ ${ }^{a}$ Faculty of Education, St Francis Xavier University, Antigonish, Nova Scotia, Canada; \\ ${ }^{b}$ School of English Language, Bilkent University, Ankara, Turkey
}

(Received 4 March 2011; final version received 31 December 2011)

\begin{abstract}
This paper explores the authors' experiences as an early career teacher educator and English-language instructor in an English-medium university in Turkey. The theoretical framework shaping their collaboration draws upon a narrative view of teacher knowledge as an embodiment of teachers' experiences in schools in close relationship with their identities. Inquiring into moments that disrupted what the authors knew as instructors, they demonstrate how thinking narratively was vital to their professional development and understanding of the complexities shaping the backdrop of their higher educational context. They situate their learning in the field of professional development at the university level and propose that thinking narratively enables instructors across the career phases and disciplines to draw upon their range of experiences in ways that offer potential opportunities for support, reflection and self-growth. This interactive process, the authors suggest, suits the aim of professional teacher development and emphasizes reciprocal learning possibilities for early career and experienced instructors working collaboratively.
\end{abstract}

Keywords: teacher knowledge; professional development; reciprocal learning; higher education; narrative inquiry

\section{Introduction}

Taking a deep breath and on the verge of beginning, a sudden movement to my left caused me to pause. I turned my head to see Hakim, ${ }^{1}$ one of the young men in the class, gesturing to his friends. Seeing their faces, smiling, it seemed, in response to his behaviour, I felt out of place and uncertain. (Jennifer's journal, 9 October 2009)

Since there was no one else in the room but us, it seemed to be a great opportunity for a private discussion. As she read, I started telling her the story underlying the proposal as a way to make things somewhat clearer. A few moments passed; she seemed to be disappointed although she had not yet said anything. Those seconds were enough for me. She gazed into space and I wondered if she was thinking there was nothing in what I had written. Perhaps she was thinking about how to express her thoughts about my paper? I was very uncomfortable. I just smiled at her. There was silence in the room. (Çiler's reconstructed field notes, 23 May 2010)

*Corresponding author. Email: jmitton@stfx.ca 
In this paper we explore how thinking narratively (Connelly and Clandinin 1990) about our experiences as an early career teacher educator and English-language instructor enriched the development of our teacher knowledge (Olson and Craig 2001; Xu and Connelly 2009) and understanding of the complexities shaping the backdrop of our higher educational context in Turkey. The opening moments are excerpts from the critical instances to be shared. By examining moments that disrupted what we knew of and hoped for ourselves as university educators, we exemplify how thinking narratively enhanced the process of our learning as individuals of different cultural backgrounds and years of teaching experience. Our twofold purpose in beginning with an excerpt of each moment is to emphasize the particularity of the narrative process in which we engaged and how we see these two instances as composing our identities as instructors in higher education. Enfolded in this latter purpose was our desire to think more deeply about the knowledge we each brought to the moment in an effort to understand not only its influence upon our teacher knowledge but its connections to the context in which we live and work (Bullough and Pinnegar 2001). We begin by providing a brief overview of how this narrative reciprocal learning process began.

In late autumn 2009 we became acquainted as a result of a conference proposal Çiler was developing about her experiences as a novice university instructor involved in an action research project. Jennifer was contacted by Çiler about the possibility of discussing her proposal. In her first year in the School of English Language as a research development coordinator in which Jennifer and Çiler were situated, Jennifer assumed their meeting would be about Çiler's upcoming conference presentation and how she might develop her paper. Prior to her arrival, Jennifer read Çiler's conference proposal and was intrigued by the following statement:

I [Çiler] will share implications regarding the role/function of professional dialogues for the empowerment of novice teachers as I believe my personal journey will shed light on the practices of many novice teachers and teacher educators in various contexts. (Excerpt from Çiler's conference proposal, 22 November 2009)

Motivated by Çiler's interest in her early career experiences, Jennifer was surprised when Çiler, during their first meeting, informed her of her withdrawal from the conference to which she had been accepted. Uncertain as to what had transpired before they met, Jennifer suggested that they continue to meet in the hopes that Çiler might reconsider her decision and further develop her work.

Beginning in this way, we moved cautiously forward, unsure of where continued dialogue might take us and uncertain of how our engagement was possibly benefitting the other, particularly as our first encounter, in which Çiler announced her withdrawal from the conference, touched upon an event in which she felt positioned as unknowing.

Our initial meeting led to weekly conversations throughout the winter and spring of 2010 and more sporadically in the fall, winter, and spring of $2011^{2}$ as we began to reflect upon our teaching experiences and the complexities informing Çiler's decision to withdraw from the conference and Jennifer's questions about her own classroom practices. Our sustained dialogue provided us opportunities in which to learn more about each other. In this way we began to attend, and later to examine more closely, the experiences we shared; instances that highlighted our 
sense of disruption and hopelessness of learning how to live and teach at the university.

Finding resonance between what we were living in and outside of the classroom enabled us to consider how experiences in different university places were shaping not only our teaching practices and social interactions, but our questions upon what we thought we knew, and believed in, about teaching and academic life. Over time we grew to understand the importance of narrative exploration informing the professional development in which we engaged, and were particularly drawn to Patrick et al.'s (2010) notion of reciprocal professional learning as a way to name some of what we were experiencing throughout this process. Patrick et al. in their study of beginning teachers and how they learned upon entering the profession, 'identified a collegiate approach as essential in this process [of teacher development]' (287). We knew that, in addition to our understanding of collaboration as vital to our development, the stories we told of our experiences were also significant to how we learned. Thinking narratively (Connelly and Clandinin 1990) about our learning process, we were drawn to Xu and Connelly's $(2009,224)$ narrative notion of life spaces as an essential conceptualization of teacher development. They write:

To summarise, narrative as method requires that teacher development begin by imagining life spaces. These spaces vary over time with the interactions of teachers' personal and social knowledge, and with place. These life spaces are fluid and dynamic and change as we work with them. A narrative approach to teacher development is something like a tai-chi movement where one gains balance by harmonizing and responding to shifting, changing, factors and forces.

What is apparent in their description is that thinking narratively about teacher development positions life experiences as influential upon an individual's continuous process of learning. Also important is an understanding of the relationship between the contextual and social particularities of place with an individual's evolving knowledge. While Xu and Connelly's emphasis is upon teacher educators and their work with pre- and in-service teachers, and ours is upon colleagues engaged in this kind of undertaking in higher education, their work helps us to conceptualize what we mean by thinking narratively as well suited to reciprocal professional learning (Patrick et al. 2010) among colleagues.

In what follows we provide an overview of the context in which we teach and establish the theoretical framework in which our work is grounded. We then show through narrative exploration (Clandinin, Pushor, and Murray Orr 2007; Connelly and Clandinin 2000; Lindemann-Nelson 2002) of how our collaboration contributed towards our professional development as instructors in a higher education setting. Later in the paper we situate our learning in the field of professional development at the university level in Turkey and propose that narrative collaborations enable instructors across the career phases and disciplines to draw upon their range of experiences in ways that offer potential opportunities for support, reflection and self-growth. This interactive process, we suggest, suits the aim of learning in faculty development, particularly beneficial for instructors situated in culturally diverse, multi-generational higher education contexts, and emphasizes reciprocal learning possibilities for early career and experienced instructors working collaboratively. 


\section{The context of our learning}

Prior to our first meeting in the late fall of 2009, we each arrived at university teaching in an English-medium higher education setting in Turkey via very different paths. In Turkey, English has no official language status yet is widely acknowledged as a means of international communication and figures prominently in Turkish national education at the $\mathrm{K}-12$ level as well as higher education (Doğançay-Aktuna and Kızlltepe 2005), a situation which scholars suggest is in response to globalization and the language's worldwide dominance in business, science and technology (Kırkgöz 2007; Kırkgöz 2009; Doğançay-Aktuna 1998). The rapid spread of English in Turkey, beginning in the 1950s, is theoretically linked to the growing global presence of American economic and military power with Turkey's desire to develop its trade relations and technology (Doğançay-Aktuna 1998). In the 1980s with international connections established and in response to increasing globalization, Doğançay-Aktuna asserted Turkey 'felt an even more urgent need to keep up in terms of foreign language proficiency. This meant language-in-education planning to aid the acquisition of English' (28). Kirkgoz (2009, 667), commenting upon the international influence of English in the Turkish context, suggested its impact may be

seen clearly on the adoption of English as medium of instruction at secondary levels and high level education and its inclusion in the school curriculum as a compulsory subject through planned policy, which has given it prominence over the other foreign languages available.

That being said, the quality of English instruction varies across types of schools and educational levels in terms of time and curricular expectations, resources and teacher qualifications, with generally those from more privileged socioeconomic classes having better access (Doğançay-Aktuna 1998; Doğançay-Aktuna and Kızıltepe 2005). Despite these inconsistencies, institutions offering English-medium education continue to be established at all levels of education (K1rkgöz 2009). At higher education, institutions providing instruction in a foreign language are required by the Turkish Council of Higher Education (CoHE) to establish foreign language preparatory schools and provide intensive study in the target language for students unable to pass language proficiency examinations upon entrance to university (CoHE 2008, 2010; for a comprehensive overview see Kirkgöz 2009). The CoHE does not prioritize the foreign language to be taught (CoHE 2010). Yet, considering the importance placed upon English internationally and its presence in the nation's public and private sectors, universities providing instruction in a language other than Turkish tend to offer English (Doğançay-Aktuna and Kızıltepe 2005) with language preparatory schools teaching English for Academic Purposes (EAP). In addition, universities offering foreign language instruction have high standing and graduates are hired in the private and public labour sectors (Mizikaci 2006).

With teaching experience in Canadian and Turkish secondary schools, upon completion of her doctoral studies in education Jennifer began working at the university as a research development coordinator in the School of English Language and as a lecturer in the Graduate School of Education in September 2009. ${ }^{3}$ Two years earlier, in the fall of 2007, Çiler, a recent university graduate from a wellestablished four-year teacher education program in Turkey, also began her university teaching career as an instructor in the university's School of English Language. 
Instructors teaching in English-language preparatory schools in English-medium universities in Turkey are considered non-tenure-track teaching staff members, different from academic staff with PhDs (CoHE 2010; Mizikaci 2006). Teaching loads and responsibilities of university instructors are determined by law and vary according to highest academic degree held with academic staff members required to get involved in research, service and supervision (Mizikaci 2006). University foreign language preparatory schools are generally classified as higher education institutes of a post-secondary school status providing instruction for a specific profession at a pre-baccalaureate level (CoHE 2010).

We emphasize the differences shaping our daily teaching experiences and backgrounds as a way to introduce the reader to the diverse complexity of the English-medium higher education setting in which we teach, one in which individuals of different years of teaching experience, educational qualifications and cultural backgrounds work alongside one another. With exception of the studyabroad program for research assistants established by the CoHE and the Ministry of Education as a way to better educate potential academic staff (Mizikaci 2006; Odabaşi 2005) alongside the two required courses doctoral candidates, from all faculties except education, take to enhance their teaching skills, professional development at the higher education level in Turkey is still an uncommon concept (Kabakc1, Odabaşi, and Kilıçer 2010; Odabași 2003; Odabași 2005). Although professional development initiatives for faculty members in information and communication technologies have been proposed (Kabakc1, Odabaşi, and Kilıçer 2010; Latchem, Odabaşi, and Kabakc1 2006), in terms of professional development for beginning teacher educators, as in Jennifer's particular situation, 'there is no professional development program [or association] that serves only teacher educators in Turkey' (Kabakc1, Odabaşi, and Kıliçer 2010, 266).

Unlike the lack of professional development opportunities in general in higher education, English-language instructors in our context and in a few other urban centres in Turkey have access to professional qualifications in the form of CELTA (Certificate in English Language Teaching to Adults), ICELT (In-Service Certificate in English Language Teaching) and DELTA (Diploma in English Language Teaching to Adults) as offered by University of Cambridge English for Speakers of Other Languages authorized centres. Also present in the country are different organizations offering professional development opportunities for English-language specialists such as The English Language Teachers' Association as well as the British Council and the United States Information Agency (K1rkgöz 2007; K1rkgöz 2009). However, in terms of learning about research as an early career English-language instructor at the university level, as in Çiler's situation, there are no opportunities other than traditional postgraduate study.

Our emphasis upon our context is deliberate. We believe that the contextual uniqueness of our situation informed the beginnings of our reciprocal learning and enabled us to experience and imagine new ways of understanding professional development at the university level from a cross-cultural, multi-generational perspective. Sharing our collaboration and the ways it benefitted our development is undertaken with the hope that our work might resonate with instructors situated in higher education settings as well as to those individuals in contexts in which professional development opportunities are limited. 


\section{Theoretical framework}

The theoretical framework shaping our work draws upon a narrative view of teacher knowledge, which considers teacher knowledge as embodying teachers' experiences in particular professional contexts informing the shaping of their identities (Xu and Connelly 2009). In this view of teacher knowledge, teachers' identities are understood as narrative constructions changing over time (Carr 1986; Clandinin and Connelly 2000; Murray Orr and Olson 2007), shaped by in and out of school experiences (Dewey 1938) informing how they teach and engage with others in particular social and professional situations. We see the conceptual notions of teacher knowledge, teacher identity and experience as essential to how we understand our professional knowledge being continuously constructed during our daily interactions with students, colleagues and others in different university places. Given our focus upon our interactions with others in the university as shaped by knowledge that is personally unique, our examination of specific experiences is informed by an understanding that much of our knowledge is tacit, that is, unvoiced formally, yet contributing to what we know and do (Johnson 1989). Xu and Connelly (2009, 222) wrote:

Tacit knowledge refers to the background knowledge people carry in their minds and bodies, a form of personal practical knowledge that governs how people approach the practical world. Disciplinary knowledge is subsumed under tacit knowledge. Rather than logically determined practical application, tacit knowledge is expressed variably, depending on the practical situation.

Particularly meaningful for us within this definition is $\mathrm{Xu}$ and Connelly's emphasis upon the ways a teacher's tacit knowledge comes forward in response to the unique circumstances of a situation. In our inquiry of personal moments, we particularly attend to actions which suggest an embodied understanding (Johnson 1989) of how the moment was being understood by us and those involved. Following Dewey, and emphasizing knowledge as embodied, Johnson $(1989,362)$ helped us see the importance of attending to 'perceptual interactions, manipulations of objects, and bodily movements' informing how we made sense of our engagement with those in specific situations. Referring to this as 'knowledge of the body', ElbazLuwisch $(2004,21)$ proposed that attending in this way creates pedagogical possibilities in how individuals might enter 'that in-between space where education can take place'. Maintaining a focus upon particular moments and considering the knowledge of our bodies as informing what we did, we see as part of delving into the meaning-making possibilities of these instances.

\section{Narrative research: linking experience to teacher knowledge and identity}

Many narrative studies examining teachers' experiences highlight the interlaced connections between teacher knowledge and the contextualized complexities shaping teachers' lives in educational settings. In addressing teachers' schooling experiences in distinctly storied and personal ways, existing narrative research is helpful in demonstrating how a teacher's knowledge is an ongoing creation, that is, knowledge that lives over time in response to experiences and relationships grounded in particular sites (Barak, Gidron, and Turniansky 2010; Carillo and Baguley 2011; Chan 2006; Chang and Rosiek 2003; Clandinin and Connelly 1996; Craig 2006; 
Craig 2007; Elbaz-Luwisch 2004; Elbaz-Luwisch 2010; Murray Orr and Olson 2007; Olson and Craig 2001; Shields 2005; Vloet and van Swet 2010).

By focusing upon teachers, and what they know, as their lives meet with others, subject matter and policies, personal complexities that are experienced in educational settings and the multiple ways teachers negotiate and learn in response, become explicit. For example, in secondary schooling, Craig's (2006) exploration of a teacher's response to a major school reform initiative brings forward this teacher's struggle as her understanding of how the arts may infuse a school curriculum lived in conflict with curricular expectations shaping the school in which she taught. Chan's (2006) narrative inquiry exploring teachers' experiences in a multicultural school context documents the multiple, unanticipated tensions that emerged for teachers in response to their attempts to implement a culturally sensitive curriculum. In higher education, Carillo and Baguley's (2011) narrative exploration of their experiences as two arts educators draws attention to the importance of induction, mentoring, training and reflection for early career academics working in the university sector. Barak, Gidron, and Turniansky's (2010) collaborative narrative selfstudy documents their professional development as a group of teacher educators through analysis of their personal career stories.

Informing this body of research are also scholars who assert the educational benefits of approaching teacher education narratively. Elbaz-Luwisch (2010) described autobiographical writing as a sustaining process in that it encourages teachers to challenge 'fixed ideas' and ask 'hard questions' of their practices and teaching contexts. Like Elbaz-Luwisch, MacIntyre-Latta and $\operatorname{Kim}(2010,138)$ also emphasized the benefits of narrative exploration and suggested that narrative work encourages educators 'to claim the creative space of praxis in their classrooms', particularly important, they argue, in an era when professional development programs in the United States are focused upon making student learning outcomes more achievable rather than teacher development supportive and educative.

Outside the formal parameters of academic study are scholars who demonstrate the ways narrative thought informs the alternative learning spaces in which teachers engage, allowing teachers to actively contribute to their knowledge base (Olson and Craig 2001). For example, Beattie et al. (2007) documented the connections between narrative inquiry and teacher development as contributing to the lifelong learning practices of eight veteran educators. Vloet and van Swet $(2010,165)$ confirmed the potential of approaching teacher development narratively and also asserted that a narrative-biographical method allows 'a good perspective on portraying professional identity as it allows us [researchers and teachers] to systematically examine both the cognitive level of professional identity and also the underlying emotions'.

It is interesting to observe that while there is a well-established global body of research recognizing the educative benefits of narrative at the in-service teacher education level, the possibilities of these benefits for teacher educators and instructors in the Turkish higher education context seem to have been overlooked. Çakıroğlu and Çakıroğlu (2003, 260), writing about their experiences as pre-service teachers, recalled that their 'teacher education program, like many others in Turkey, was trying to give us a knowledge base which was not relevant to the realities of Turkish schools'. They further proposed that 'the ability to understand local issues cannot be ensured unless there is an effort to study research questions aimed at a local audience' (262). Their work also informs our intent to address the need for 
experiential research that focuses upon teachers' experiences and their knowledge situated in Turkey, particularly research that honours teacher knowledge not from a deficit stance, but with an understanding that teacher knowledge is comprised of experiences, academic, professional and personal, unfolding in relationship with others in particular settings (Connelly and Clandinin 2000; Xu and Connelly 2009).

In what follows we maintain a focus upon the meaning of two storied moments to consider how our collaborative inquiry into these instances contributed to our professional development.

\section{Critical moments}

\section{Stumbling in the life space: experiences in university places}

\section{Jennifer in a university classroom}

Picking up the children's book Chrysanthemum (Henkes 2001), I introduced it to the 23 pre-service teachers seated before me. I apologized for the lack of an OHP with which to share the illustrations and promised to show the pictures after I read each page. Taking a deep breath and on the verge of beginning, a sudden movement to my left caused me to pause. I turned my head to see Hakim, one of the young men in the class, gesturing to his friends. Seeing their faces, smiling it seemed in response to his behaviour, I felt out of place and uncertain. I wondered if my use of a picture book in a pre-service teacher curriculum course was their source of amusement. Aware of my gaze, the young men pulled their smiles in; dropping their eyes they left Hakim on his own. Keeping my tone light I said, 'You never know Hakim you, too, may fall in love with children's literature and want to use it in your future classroom.' He didn't respond and I proceeded to read aloud.

Later in the morning with 10 minutes to go in the midst of explaining the readings for the following week, Hakim asked, 'Teacher isn't the time up?' My face felt tight as I replied 'Good try, Hakim, we have some time remaining.' The class soon finished and Hakim departed quickly. This moment was some days ago but my memory of it has lingered. (Jennifer's journal, 9 October 2009)

\section{Çiler in a university staff room}

I walked into the teacher's room eager to share the proposal of my first conference paper with one of my colleagues. I am sure my face belied my excitement. Since there was no one else in the teacher's room but us, it seemed to be a great opportunity for a private discussion. As she read, I started telling her the story underlying the proposal as a way to make things somewhat clearer. A few moments passed; she seemed to be disappointed although she did not speak. She gazed into space and I wondered if she was thinking there was nothing in what I had suggested. Perhaps she was thinking about how to express her thoughts about my paper? I was uncomfortable and just smiled at her. It seemed she had something on her mind but was afraid to speak. I did not know how to react so I kept talking. When she finally began to speak, she suggested that although she knew I was doing my best, it was too early for me to think about research. It seemed I did not know how to write an academic paper as of yet. Thanking her for her time, I returned to the classroom and stayed busy to push back the deep disappointment I felt. I soon notified the conference committee and withdrew my submission. (Çiler's reconstructed field notes, 23 May 2010) 


\section{Reciprocal learning through collaborative inquiry}

Attending to the temporal, social and contextual dimensions (Clandinin, Pushor, and Murray Orr 2007) shaping these moments, we began to see how we were both in the midst of transitional stages in our teaching lives. Thinking in this way, we saw these particular instances as possibilities for understanding how we both attempted to live out ourselves at the intersection of ours and others' narratives (Xu and Connelly 2009). The three commonplaces of temporality, sociality and place (Clandinin, Pushor, and Murray Orr 2007; Connelly and Clandinin 2006) guided our thinking in terms of the analytical questions we asked as we considered the influence of these moments upon our subsequent actions. In the following pair of narratives, we share backwards- and sidewayslooking stories (Lindemann-Nelson 2002) as a way to emphasize the interaction of our past experiences informing our actions in these instances and afterwards.

\section{Jennifer's life space: Looking backwards and sideways as a way to see forward}

Informed by positive community experiences in different educational contexts, of particular importance to me upon arrival to the university was establishing an inquiry space in which in-service English-language instructors had the opportunity to share and reflect upon their own teaching and research practices. Alongside my efforts at establishing an inquiry community was life inside my classroom. As part of my teaching responsibilities that first year, I taught teacher candidates and experienced teachers in two different postgraduate programs located on two different campuses of the university.

One of the courses I taught was an introduction to curriculum and instruction course to a group of 23 pre-service teachers specializing in the secondary teaching of biology, Turkish language and literature, mathematics, history and English. The majority of the students were second-language speakers of English and many had confessed that I was their first 'foreign' teacher. Some of the students were from Ankara while others were from smaller urban centres located across Turkey. The class also included an American woman, five Iraqi men and one woman, and me, their instructor, an individual from the Canadian Maritimes who, at the time, had been living in Turkey since 1998. This class was also my first time teaching undergraduate students and it happened on a different campus from where I did the majority of my teaching. Because of this, I only saw this group once a week for two hours, making me feel like a stranger each time I stepped into the room with them, a feeling that did not begin to dissipate until two months after the course had begun.

On the October morning in which I used the children's book Chrysanthemum (Henkes 2001), I was hopeful the book might provide an opportunity for us to apply some of the curriculum concepts we had been discussing during the initial weeks of the course. Before introducing the book I recall my nervousness and was keen for their approval. My perception of Hakim and his response to the book suggests to me I was bringing in a text he was unused to seeing in a university classroom and that I was hopeful that he and his classmates would respond to the book in ways that I was used to, ways that reminded me of previous graduate students I had taught. Assuming he was disregarding not only the book but also me as a tea- 
cher, I remember my deep sense of disappointment and it was not until towards the end of the course in December that I decided to try another book of children's literature with this particular class.

\section{Çiler's life space: Looking backwards and sideways as a way to see forward}

Encouraged by a positive experience during my second year of teaching as a member of an action research group focused upon classroom practice, I felt ready to start something on my own thanks to the encouragement that I received from experienced colleagues involved in the project. During my first two years of teaching EAP, I observed that due to busy timetables it was not always easy for me to learn from more experienced colleagues in spontaneous kinds of ways. I was looking for an opportunity in which I might be able to ask questions and learn from those around me. In the winter semester of my second year, a colleague gave a presentation about the possibilities of action research for classroom teaching. After the meeting, I approached her and asked if I could help with anything related to the project. At the time, I saw myself as assisting as opposed to being a full project member. A few days later I was officially invited to become a part of the project team by my line administrator. I expressed my concerns that because I was young and new to the profession, I did not think I could contribute to their work. She assured me that my presence would help the group; I agreed to join despite my apprehension.

Over time my confidence grew and I began to keep a journal about our meetings and the progress I wanted to make in my teaching. The writing helped; my enthusiasm for the project increased. During the meetings we shared our experiences in the classroom and generated data in response to the teaching methods we were trying. I began to see the ways in which I could change and adapt to what students seemed to need.

Six months after the action research initiative ended, I was anxious to share with others what I had learned as a novice teacher during the project. I shared the conference abstract with my colleague in one of the school's unit rooms, which approximately 15 teachers share. On a day in which the teacher's room was busy, I would never have discussed my paper. I did not feel comfortable openly sharing that I, a young teacher, was preparing a paper to present at a conference. I was concerned that my colleagues might think I was attempting to show that I knew more than they did. On this day, however, the only person present was an individual I knew as experienced and helpful to young teachers. Because I felt a fresh perspective was important, I thought she might be able to offer me constructive feedback on my writing efforts.

Looking back now I believe I had expected her to talk with me like others had done on the action research project. Believing that she was disregarding my efforts as amateurish, in the moment I recall my embarrassment and desire to leave the room. It is possible she also felt uncomfortable as well in that my understanding of research differed from her understanding. Perhaps she was unfamiliar with the framework in which I situated my work and because of that was reluctant to respond. My immediate response to this conversation, however, was to withdraw from the conference. 


\section{Pressing collaboratively forward: sharing, inquiring, pinpointing and connecting}

\section{Sharing and inquiring}

Puzzling through our narratives, we returned to our first stories and likened these tellings to photographs frozen in time, un-nested from the complexity of who we were at different junctures of our teaching careers. Although initially sharing these experiences was essential in our subsequent learning, left in their static state, little about them can be said as contributing to the development of our teacher knowledge. Making sense of our first tellings through backwards- and sideways-looking stories (Lindemann-Nelson 2002) positioned these instances in the temporal life flow (Xu and Connelly 2009) of our knowledge and identities. Xu and Connelly $(2009,234)$ wrote:

The sphere flows temporally, like a river, changing as we watch it. Events and persons in the sphere interact personally and socially, in different ways at different places, and at different times. Coming to grips with this life space is the task of a narrative approach to teacher development.

While inquiring into our first stories, we drew upon what we knew about the other, ideas that had been learned in conversation over time. Inquiring in this way enabled us to see possibilities in what had unfolded in a class and staff room, that is, new ways to understand these particular events in relation to who we were. For example, in how Çiler reminded Jennifer of the teacher-centred educational system from which the student in Jennifer's curriculum class emerged and in how Jennifer suggested to Çiler her colleague's possible unfamiliarity with the kind of reflective practice Çiler proposed to present in her paper. Seeing possibilities in each other's storied experiences, possibilities informing our interactions with others, brought forward understanding about our possible responsibility in what occurred and why the moments impacted our lives in the ways that they did.

Understanding our participation in the event shifted the emphasis from what, we felt, others had done to us to our probable contributions in their unfolding. In terms of self-learning this was a profound shift allowing us to think more deeply about how Çiler's colleague felt after their conversation and how Jennifer's student felt upon departure from the classroom. Drawing upon Xu and Connelly's (2009) metaphor of the life space as like a river, we learned with each other that we, too, have the potential to create influential currents in others' lives.

\section{Pinpointing resonance}

In our attempt to collaboratively better understand these moments, also adding meaning was pinpointing the resonance between our experiences, particularly in terms of how inexperienced and uncertain we felt. Uncertainty made us vulnerable as seen in Çiler's withdrawal from the conference and in how Jennifer dropped children's literature for a period of time from her classes. We saw this pinpointed resonance as representative, in some ways, of our lives in the university at that time, that is, this particular context could be a lonely place and it was not for the unsure. Helping us to make sense of this feeling was Lakoff and Johnson's (1980, 3) work on metaphors in which they suggest metaphors 'are not just matters of the intellect' for they 'also govern our everyday functioning ... what we perceive, how we get 
around in the world, and how we relate to other people'. Meaningful for us within Lakoff and Johnson's conceptual framework is their emphasis upon how metaphors, as embedded in conversation, provide possibilities for negotiated meaning between people of different cultures in that you 'bend your world view and adjust the way you categorize your experience ... to communicate the relevant parts of unshared experiences $\ldots$ or to highlight the shared experiences' (231). Mindful of our different heritage informing our identities, we looked upon those moments in which metaphors were used to describe our feelings as instances of negotiated understanding between us.

\section{Connecting to the larger context}

Thinking about the process in which we engaged, a process we have come to think of as sharing, inquiring, pinpointing and connecting, emphasizes the potential of approaching professional learning from a reciprocal (Patrick et al. 2010), narrative (Xu and Connelly 2009) stance in that we, individuals with different years of teaching experience and different cultural backgrounds, learned from the other about our identities as teachers and how we might move forward as university instructors. A narrative, reciprocal approach to professional learning is an inquiry process that is critically reflective, supportive, mutual and educative, a kind of learning that holds much potential for teachers in a variety of educational contexts as the literature has established (Barak, Gidron, and Turniansky 2010; Chan 2006; Chang and Rosiek 2003; Clandinin and Connelly 1996; Craig 2006; Craig 2007; Elbaz-Luwisch 2004; Elbaz-Luwisch 2010; Olson and Craig 2001). Our emphasis upon higher education contexts is not done to exclude the possibilities of narrative, reciprocal partnerships for teachers in other settings of learning. Indeed, we believe narrative collaborations are potentially beneficial for all teachers (Carillo and Baguley 2011; Savvidou 2011; Shields 2005; Vloet and van Swet 2010). Rather, our emphasis upon postsecondary terrains, particularly in terms of education and English-language teaching, is to highlight how we professionally learned in an educational context more inclined to acknowledge other disciplines. Kosnik and Beck $(2008,186)$, in their description of how the field of education is viewed in the North American context, suggested those connected to education are:

Often viewed as lacking scholarship, their classes devoid of substance, and their intellectual focus too school-based. Those who hold the title of 'education professor' putatively are held to a lesser standard than faculty colleagues from liberal arts departments and other professional schools across our campuses.

Their point resonated deeply with us as we noted what we were living, that is, the lack of connections with other faculties and professional development opportunities in order to further develop our own scholarly interests. A professional situation that Odabaşi (2005) suggested creates a lack of serious interest in teaching and professional learning at the university level in Turkey. While we are mindful of the impact our collaboration has had upon our growth and its relevance for the Turkish context, we are also aware of the importance of considering how our learning is pertinent to other educational settings (Bullough and Pinnegar 2001). In what follows, we bring forward four insights. Each has a particular influence and significance given our experiences and the context in which these occurred; yet, we 
believe, they also hold importance for teachers in a range of particular situations and settings.

\section{Insight 1: Teachers as researchers}

As previously described, in Turkey there is little opportunity outside of formal study for early career English-language instructors in higher education to learn about research and the ways it might serve their practice as in-service teachers. Ciler's situation speaks to the struggles teachers encounter as they attempt to conduct classroom research and shape their ideas into academic papers (Smiles and Short 2006) while balancing multiple teaching responsibilities ( $\mathrm{Li}$ 2005; Massey et al. 2009). It is also important to acknowledge that Çiler during her initial attempt at developing a conference paper feared her colleagues' response in that she felt they might see her as someone who thought she knew more than she did. Kosnik and Beck (2008) in their study of non-tenure teacher educators found this situation had the potential to create a feeling for participants of not truly belonging at the university or at the school at which they originally taught. One of the lessons we took from this aspect of Çiler's experience is that the potential was there for Çiler to not follow up on her professional learning due to her twofold concern of not being ready for academic pursuits, based upon the advice given by a colleague, compounded by the possibility of being socially isolated from her colleagues. Zeichner (2003) argued that more needs to be known about the experiences of teachers who conduct research as much emphasis in the established literature about teachers as researchers is placed upon finished products rather than what happens throughout the journey. Çiler's experience speaks to the life complexity of her undertaking as a novice teacher researcher.

\section{Insight 2: Issues of identity}

We also noted the lack of professional development opportunities for teacher educators in general in Turkey, a situation particularly challenging for those like Jennifer at the beginning of their careers as they attempt to establish new professional identities (Carillo and Baguley 2011; Murray and Male 2005; Swennen, Shagrir, and Cooper 2009). In significant ways Jennifer's teaching experience points to what Loughran (2006) suggested is one of the challenges of becoming a teacher educator in that you cannot replicate what you might have done as a teacher in a K-12 setting, a transition that Murray and Male (2005) described as a time of stress and uncertainty. Another way to think about this period of time in Jennifer's career as she attempted to balance teaching alongside writing and publishing is the implication that functioning as both a teacher and researcher in the field of education situates teacher educators in a context of competing viewpoints about practitioner research (Cochran-Smith 2005). Such competing viewpoints about the purpose of practitioner research and its worth also points to the possibility that Jennifer, like Çiler, might have also not pursued her own professional learning due to workload and lack of opportunity. Jennifer's experience speaks to the challenges of establishing a new professional identity as a teacher educator where one is an expert in some ways but feels like a novice in others (Murray and Male 2005). 


\section{Insight 3: Awareness of context}

A significant aspect that emerged from our collaboration was newfound awareness of the social complexities shaping multiple places in our university context. Hunter et al. $(2011,42)$, in their study of school staff rooms as important professional learning spaces for beginning teachers, suggested that such spaces 'should not be underestimated if teacher retention or the development of professional learning and professional cultures is of any significance'. As we think of the profound experience each of us had with others in different university places, specifically a classroom and staff room, and their influence upon how we felt for a time about ourselves as educators and scholars, we are mindful of how different our experiences might have been in those moments had they been lived in other places in the university. For example, had Çiler met her colleague in a busy café or if others had been present in the staff room with Çiler and her colleague would the experience have unfolded in the ways that it did? Or, for instance, had Jennifer interacted with the student in the hallway outside of the classroom would the exchange between them have occurred? Dwelling upon the importance of place brings forward again the importance of our collaboration and the ways puzzling through these moments, seeing them as spatially, temporally, socially and historically contained, enabled us to see what ourselves, and others, were possibly attempting to live out in the moment. Thinking of contexts and their significance in our experiences also encouraged us to broaden our inquiry and from there we reviewed relevant literature (CoHE 2008, 2010; Kabakc1, Odabaşi, and K1lıçer 2010; Kırkgöz 2009; Latchem, Odabaşi, and Kabakç1 2006; Mizikaci 2006; Odabaşi 2003; Odabaşi 2005) which created new understanding of the broader educational context in which we were situated, thereby, in many ways, enabling us to name some of what we experienced in terms of policies, procedures and educational trends rather than a deficit in our own knowledge.

\section{Insight 4: Cross-cultural dialogue informing our collaborative empowerment}

Each of the preceding points leads to an understanding of a teacher's professional learning as part of who they are (Xu and Connelly 2009). When professional learning is treated as an extra and not as integral to a teacher's identity much is lost (Olson and Craig 2001). Left on our own, the potential for both of us to have given up on our professional learning was a very real possibility and points to the challenges of sustaining learning that is personally meaningful in competitive university contexts. Purposefully inquiring into our storied experiences encouraged us to see alternatives to what we were living as well as to reciprocally learn from one another in different ways; for example, in how Jennifer offered Çiler guidance in terms of research and in how Çiler provided Jennifer new understanding about the cultural, social context in which we were situated. Both of us had knowledge that was helpful to the other and our sharing allowed each of us to learn in purposeful ways, that is, adapt our practices, cultivate new awareness for what was happening around us and develop plans of future action.

Much of the literature has focused upon the benefits of teachers conducting research in the ways it positively contributes to the development of teacher knowledge, inquiry and practice (Babkie and Provost 2004; Ballenger and Roseberry 2003; Cochran-Smith and Lytle 1999, Cochran-Smith, 2004; Massey et al. 2009), 
of inclusive forms of pedagogy (Capobianco et al. 2006; Massey et al. 2009; Savvidou 2011), and of feelings of teacher empowerment (Esposito and Smith, 2006; Massey et al. 2009). While this body of work resonates with what we lived, it is also important to emphasize cross-cultural dialogue as significant in this process. As previously shared, we are widely different in terms of our cultural backgrounds and upbringing, and helping us make sense of the stories we shared was pinpointing resonance through the metaphors (Lakoff and Johnson 1980) that we used to describe our experiences in different places in the university. Research has demonstrated how storytelling potentially helps teachers challenge their assumptions about diversity and consider new ways of addressing multicultural issues in schools (Boone and Chan 2005; Li 2005). In our situation, the metaphors that were embedded in our stories, specifically in the ways we felt the university was a competitive and lonely landscape, allowed us to understand what we shared and negotiate meaning between us. By focusing upon our experiences and the resonance between them, our dialogue, informed by our different cultural perspectives, was less theoretical and more focused upon the exploration of an issue that was critically important and personally significant.

\section{Conclusion}

This inquiry into two moments nested in the experiences of an early career teacher educator and English-language instructor provides an up-close look at teacher knowledge as developing and benefitting from narrative collaboration. In this paper, sharing a detailed narrative account was purposeful in that we wanted to illustrate how narrative research might be collaboratively undertaken in terms of professional learning while also providing the opportunity for readers to interact with the text and bring forward interpretations relevant to their experiences and contexts $(\mathrm{Xu}$ et al. 2007). We have begun to talk about the significance of reshaping new understandings of professional development in higher education and call for narrative collaborations to be documented not only as evidence of the sustaining power such partnerships hold but also as a resource for those in the field from which they might learn practically and pedagogically. The complex work of what we do at the university encourages us to be to innovative in terms of professional learning and to create opportunities in which we might learn 'from all kinds of experiences, positive as well as less successful experiences' (Smith 2003, 213).

\section{Acknowledgements}

We would like to express our thanks to Martie Geertsema and Erhan Kükner for their helpful feedback on our paper.

\section{Notes}

1. Other than the authors', any names mentioned in the paper are pseudonyms.

2. Due to our respective teaching schedules, we met when we could and were in touch through email correspondence.

3. Jennifer worked in this context from September 2009 until June 2011.

\section{Notes on contributors}

Jennifer Mitton-Kükner is an assistant professor working in the Faculty of Education at St Francis Xavier University in Antigonish, Nova Scotia, Canada. Her research interests 
include teacher education and development, alternative learning spaces and narrative research.

Çiler Akyüz is a graduate of Middle East Technical University, Department of English Language Teaching. She currently works as an instructor at Bilkent University School of English Language in Ankara, Turkey. Her research interests are professional development, testing and narrative inquiry.

\section{References}

Babkie, A.M., and M.C. Provost. 2004. Teachers as researchers. Intervention in School and Clinic 39, no. 5: 260-8.

Ballenger, C., and A.S. Roseberry. 2003. What counts as teacher research? Investigating the scientific and mathematical ideas of children from culturally diverse backgrounds. Teachers College Records 105, no. 2: 297-314.

Barak, J., A. Gidron, and B. Turniansky (with the collaboration of Adiba Arafat, Dina Friling, Ruth Mansur, Marga Simca, Smadar Tuval and Talia Weinberger). 2010. 'Without stones there is no arch': A study of professional development of teacher educators as a team. Professional Development in Education 36, no. 1: 275-87.

Beattie, M., D. Dobson, G. Thornton, and L. Hegge. 2007. Interacting narratives: Creating and re-creating the self. International Journal of Lifelong Education 26, no. 2: 119-41.

Boone, M., and E. Chan. 2005. Gaining interpretive competence through cross-cultural dialogue among teachers and researchers. McGill Journal of Education 40, no. 1: 95-108.

Bullough, R.V., and S. Pinnegar. 2001. Guidelines for quality in autobiographical forms of self-study research. Educational Researcher 30, no. 13: 13-21.

Çakıroğlu, E., and J. Çakıroğlu. 2003. Reflections on teacher education in Turkey. European Journal of Teacher Education 26, no. 2: 253-64.

Capobianco, B.M., S. Lincoln, D. Canuel-Browne, and R. Trimarchi. 2006. Examining the experiences of three generations of teacher researchers through collaborative science inquiry. Teacher Education Quarterly Summer 30, no. 3: 61-78.

Carillo, C., and M. Baguley. 2011. From school teacher to university lecturer: Illuminating the journey from the classroom to the university for two arts educators. Teaching and Teacher Education 27: 62-72.

Carr, D. 1986. Time, narrative, and history. Bloomington: Indiana University Press.

Chan, E. 2006. Teacher experience of culture in curriculum. Journal of Curriculum Studies 38, no. 2: 161-76.

Chang, P.J., and J. Rosiek. 2003. Anticolonialist antinomies in a biology lesson: A sonataform case study of cultural conflict in a science classroom. Curriculum Inquiry 33, no. 3: $252-90$.

Clandinin, D.J., and F.M. Connelly. 1996. Teachers' professional knowledge landscapes: Teacher stories - Stories of teachers - School stories - Stories of schools. Educational Researcher 25, no. 3: 24-30.

Clandinin, D.J., and F.M. Connelly. 2000. Narrative inquiry: Experience and story in qualitative research. San Francisco: Jossey-Bass.

Clandinin, D.J., D. Pushor, and A. Murray Orr. 2007. Navigating sites for narrative inquiry. Journal of Teacher Education 58, no. 1: 21-35.

Cochran-Smith, M. 2004. Walking the road: Race, diversity and social justice in teacher education. New York, NY: Teachers College Press.

Cochran-Smith, M. 2005. Teacher educators as researchers: Multiple perspectives. Teaching and Teacher Education 21: 219-25.

Cochran-Smith, M., and S. Lytle. 1999. Relationships of knowledge and practice: Teacher learning in communities. Review of Research in Education 24, no. 1: 249-305.

CoHE. See Council of Higher Education.

Connelly, F.M., and D.J. Clandinin. 1990. Stories of experience and narrative inquiry. Educational Researcher 19, no. 5: 2-14. 
Connelly, F.M., and D.J. Clandinin. 2000. Teacher education: A question of teacher knowledge. In Tomorrow's teachers: International and critical perspectives on teacher education, ed. J. Freeman-Moir and A. Scott, 89-105. Christchurch: Canterbury University Press/Christchurch College of Education.

Connelly, F.M., and D.J. Clandinin. 2006. Narrative inquiry. In Handbook of complementary methods in education research, ed. J. Green, G. Camilli, and P. Elmore, 375-85. Mahwah, NJ: Lawrence Erlbaum.

Council of Higher Education. 2010. The higher education system in Turkey. Ankara: CoHE. http://www.yok.gov.tr/katalog/The_higher_education_system_in_turkey.pdf.

Council of Higher Education. 2008. Yükseköğretim kurumlarinda yabanci dil öğretimi ve yabanci dille öğretim yapilmasinda uyulacak esaslara ilișkin yönetmelik [online]. [Regulations on foreign language teaching in the institutions of higher education and on the basis of the implementation of education and training in a foreign language]. Resmi Gazete [Official journal] no. 27074. http://www.yok.gov.tr/content/view/471/183/lang,tr/ (in Turkish).

Craig, C. 2006. Why is dissemination so difficult? The nature of teacher knowledge and the spread of curriculum reform American Educational Research Journal 43, no. 2: 257-93.

Craig, C. 2007. Story constellations: A narrative approach to contextualizing teachers' knowledge of school reform. Teaching and Teacher Education 23: 173-88.

Dewey, J. 1938. Experience and education. New York: Touchstone.

Doğançay-Aktuna, S. 1998. The spread of English in Turkey and its current sociolinguistic profile. Journal of Multilingual and Multicultural Development 19, no. 1: 24-39.

Doğançay-Aktuna, S., and Z. Kızıltepe. 2005. English in Turkey. World Englishes 24, no. 2: 253-65.

Elbaz-Luwisch, F. 2004. How is education possible when there's a body in the middle of the room? Curriculum Inquiry 34, no. 1: 9-28.

Elbaz-Luwisch, F. 2010. Writing and professional learning: The uses of autobiography in graduate studies in education. Teachers and Teaching: Theory and Practice 16, no. 3: 307-27.

Esposito, J., and S. Smith. 2006. From reluctant teacher to empowered teacher researcher: One educator's journey toward action research. Teacher Education Quarterly Summer: $45-60$.

Henkes, K. 2001. Chrysanthemum. New York: Greenwillow Books.

Hunter, L., T. Rossi, R. Tinning, E. Flanagan, and D. MacDonald. 2011. Professional learning spaces and places: The staffroom as a site of beginning teacher induction and transition. Asia-Pacific Journal of Teacher Education 39, no. 1: 33-46.

Johnson, M. 1989. Embodied knowledge. Curriculum Inquiry 19, no. 4: 361-77.

Kabakçı, I., H.F. Odabaşi, and K. Kılıçer. 2010. Transformative learning-based mentoring for professional development of teacher educators in information and communication technologies: An approach for an emerging country. Professional Development in Education 36, no. 1: 263-73.

Kırkgöz, Y. 2007. Language planning and implementation in Turkish primary schools. Current Issues in Language Planning 8, no. 2: 174-91.

Kırkgöz, Y. 2009. Globalization and English language policy in Turkey. Educational Policy 23: $663-84$.

Kosnik, C., and C. Beck. 2008. In the shadows: Non-tenure-line instructors in pre-service teacher education. European Journal of Teacher Education 31, no. 2: 185-202.

Lakoff, G., and M. Johnson. 1980. Metaphors we live by. Chicago: University of Chicago Press.

Latchem, C., H.F. Odabaşi, and I. Kabakçı. 2006. Online professıonal development for university teaching in Turkey: A proposal. The Turkish Online Journal of Educational Technology 5, no. 3: 20-6.

Li, X. 2005. A tao of narrative: Dynamic splicing of teacher stories. Curriculum Inquiry 35, no. 3: 339-65.

Lindemann-Nelson, H. 2002. Context: Backward, sideways, and forward. In Stories matter: The role of narrative in medical ethics, ed. R. Charon and M. Montello, 39-47. London: Routledge.

Loughran, J. 2006. Developing a pedagogy of teacher education: Understanding teaching and learning about teaching. New York: Routledge. 
MacIntyre-Latta, M., and J. Kim. 2010. Narrative inquiry invites professional development: Educators claim the creative space of praxis. The Journal of Educational Research 103: $137-48$.

Massey, D.D., P. Baber, J. Lowe, A. Ormond, and J. Weatherly. 2009. Teacher research: Who is it for and what is the point? Journal of Curriculum and Instruction 3, no. 1: 47-61.

Mizikaci, F. 2006. Monographs in higher education: Higher education in Turkey. Bucharest: UNESCO-CEPES. http://unesdoc.unesco.org/images/0014/001455/145584e.pdf.

Murray, J., and T. Male. 2005. Becoming a teacher educator: Evidence from the field. Teaching and Teacher Education 21: 125-42.

Murray Orr, A., and M. Olson. 2007. Transforming narrative encounters. Canadian Journal of Education 30, no. 3: 819-38.

Odabași, H.F. 2003. Faculty point of view on faculty development. Hacettepe Üniversitesi Eğitim Fakültesi Dergisi 24: 86-9.

Odabaşi, H.F. 2005. The status and need for faculty development in Turkey. International Journal for Academic Development 10, no. 2: 139-42.

Olson, M., and C. Craig. 2001. Opportunities and challenges in the development of teachers' knowledge: The development of narrative authority through knowledge communities. Teaching and Teacher Education 17: 667-84.

Patrick, F., D. Elliot, M. Hulme, and A. McPhee. 2010. The importance of collegiality and reciprocal learning in the professional development of beginning teachers. Journal of Education for Teaching 36, no. 3: 277-89.

Savvidou, C. 2011. Exploring teachers' narratives of inclusive practice in higher education. Teacher Development 15, no. 1: 53-67.

Shields, C. 2005. Using narrative inquiry to inform and guide our (re)interpretations of lived experience. McGill Journal of Education 40, no. 1: 179-88.

Smiles, T.L., and K.G. Short. 2006. Transforming teacher voice through writing for publication. Teacher Education Quarterly 33, no. 3: 133-47.

Smith, K. 2003. So, what about the professional development of teacher educators? European Journal of Teacher Education 26, no. 2: 201-15.

Swennen, A., L. Shagrir, and M. Cooper. 2009. Becoming a teacher educator: Voices of beginning teacher educators. In Becoming a teacher educator: Theory and practice for teacher educators, ed. A. Swennen and M. van der Klink, 91-102. Dordrecht: Springer.

Vloet, K., and J. van Swet. 2010. 'I can only learn in dialogue!' Exploring professional identities in teacher education. Professional Development in Education 36, no. 1: $149-68$.

$\mathrm{Xu}$, S., and F.M. Connelly. 2009. Narrative inquiry for teacher education and development: Focus on English as a foreign language in China. Teaching and Teacher Education 25: 219-27.

Xu, S., F.M. Connelly, M.F. He, and J. Phillion. 2007. Immigrant students' experience of schooling: A narrative inquiry theoretical framework. Journal of Curriculum Studies 39, no. 4: 399-422.

Zeichner, K. 2003. Teacher research as professional development for P-12 educators in the USA. Educational Action Research 11, no. 2: 301-26. 